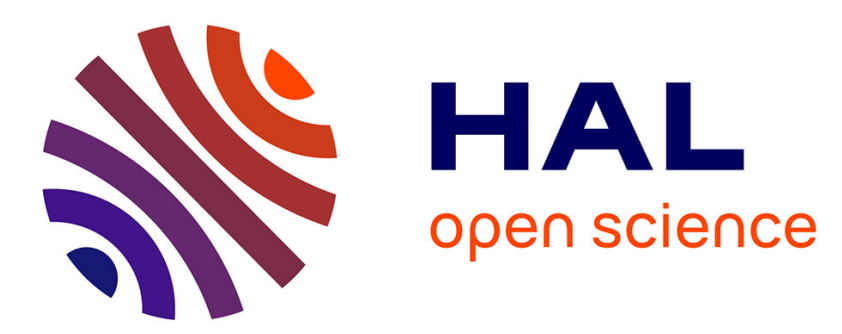

\title{
Institutional and/versus commercial media coverage: representations of the University of California, Berkeley-Novartis agreement
}

\author{
Alan Rudy, Toby A. Ten Eyck
}

\section{- To cite this version:}

Alan Rudy, Toby A. Ten Eyck. Institutional and/versus commercial media coverage: representations of the University of California, Berkeley-Novartis agreement. Public Understanding of Science, 2006, 15 (3), pp.343-358. 10.1177/0963662506063795 . hal-00571093

\section{HAL Id: hal-00571093 \\ https://hal.science/hal-00571093}

Submitted on 1 Mar 2011

HAL is a multi-disciplinary open access archive for the deposit and dissemination of scientific research documents, whether they are published or not. The documents may come from teaching and research institutions in France or abroad, or from public or private research centers.
L'archive ouverte pluridisciplinaire HAL, est destinée au dépôt et à la diffusion de documents scientifiques de niveau recherche, publiés ou non, émanant des établissements d'enseignement et de recherche français ou étrangers, des laboratoires publics ou privés. 


\title{
Institutional and/versus commercial media coverage: representations of the University of California, Berkeley-Novartis agreement
}

\begin{abstract}
Alan Rudy and Toby A. Ten Eyck
In 1998, a contract was signed between the University of California at Berkeley (UCB) and Novartis in which the latter agreed to give UCB's Department of Plant and Microbial Biology US\$25 million over a five year period. This Agreement was the foundation for debates that split the university over issues related to corporate control of the university, the environmental and social consequences of biotechnology, intellectual property rights, and academic freedom. This paper investigates the ways in which the Agreement was presented within the public relations office of UCB and the popular press, as well as reactions to that coverage. Data were collected through archival and web-based searches and interviews with individuals connected to the Agreement.
\end{abstract}

\section{Introduction}

In October 1998, a five year, US\$25 million deal was announced between the University of California at Berkeley (UCB) and Novartis, a large Switzerland-based agricultural, pharmaceutical, and biotechnology firm. The terms of the Agreement provided the faculty of the Plant and Microbial Biology Department (PMB) at UCB US\$5 million annually for five years to distribute among the faculty through an internal competitive allocation process. In exchange, Novartis obtained first right of refusal of all departmental patents-independent of funding source unless explicitly excluded by other funding agencies-equivalent to the percentage of total departmental research funding that comprised the US\$5 million. ${ }^{1}$ In addition to the anticipation of valuable patent licenses, Novartis hoped to jump start its newly established, La Jolla-based, Novartis Agricultural Discovery Institute (NADI) through collaborative research related to the Agreement.

Importantly, however, the Dean of the College of Natural Resources negotiated with the university administration for the College to recover a surprising proportion of the university's indirect costs-promising to use the funds for the good of the College as a whole. This recovery led a number of non-PMB faculty and graduate students in the College to feel that they would be perceived by their peers and others as compromised due to their association with the Agreement, without playing a role in the negotiations. Under these conditions, the Agreement (hereafter referred to as UCBNA) touched off a conflagration of 
already smoldering debates as to the changing role of universities in society, the appropriateness of this sort of private funding at a public university, and the consequences of such relationships for academic freedom and intellectual diversity within the College of Natural Resources and the university as a whole.

Our focus in this paper is to describe and analyze the context, contestation, and constructions of UCBNA, particularly with respect to the public face of the relationship as portrayed by UCB's public relations office and the popular press. Distilling the essence of the controversy finds two key points about participants: 1) they lacked shared assumptions as to what the controversy was about, and, therefore, 2) exhibited strong tendencies to talk past one another. To proponents of the Agreement, opponents were linking the Agreement to genetically modified agricultural products - an issue controversial on a global scale (e.g., Gaskell and Bauer, 2001; Nottingham, 1998). To opponents, the heart of the issue lay in the extent, possible consequences, and apparent trajectory of the encroachment of industrial interests into the academy's pursuit of public science. The environmental and social consequences of biotechnology were, for opponents, more about the environment and state of the university than agricultural and rural environments.

Following Schonbach's (1990) analysis of the consequences of divergent accounts in the context of norm breaking actions, it can be argued that the failure of the two sides in the controversy to share a common construction of the problem - to have the Agreement serve as a functional boundary object (Star and Greisemer, 1989)-inflamed the controversy. It is quite obvious that throughout the negotiation and progress of the now-terminated Agreement, each side felt (and continues to feel) that the other side was neither listening to nor acknowledging their central concerns. ${ }^{2}$

We start our study with a quick review of the literature on the evolving structure and characterization of universities in Western society focusing on the graying of the line between the spheres of public and private technoscientific development. Following this, a history of the Agreement is provided to ground the analysis of the media coverage and contestation, in addition to some background on UCB's contested relationship with its Progressive science- and efficiency-based past and its Populist service- and reform-based legacies.

\section{A brief history of the role(s) of universities}

For over one hundred years, contestation over the role of universities in the United States has been connected to different commitments to variants of C.P. Snow's (1959) "two cultures"- those of the humanities and those of the (natural) sciences (often with the social sciences operating in between and therefore rejected by both sides). This divide recapitulates historical, German debates as to whether or not the university is primarily intended to foster the improvement of the citizenry and inculcation of national culture as opposed to the development of pure science and applied technology (Readings, 1996; Miyoshi, 1998). For most of the twentieth century, disciplines within each "culture" focused on defining their boundaries and establishing, institutionalizing and policing "normal scientific" practices and programs (Kuhn, 1962; Lakatos and Musgrave, 1970).

Over the past quarter century, however, both the cultural and technoscientific problems of our day have become ever more hybrid in character (Haraway, 1985; Law, 1991; Latour, 1993) at the same time that the "filling in" of interdisciplinary locations between cousin disciplines has altered institutional and disciplinary coherence. As disciplines and departments have been restructured, both the fiscal underpinnings and cultural stability of 
traditional universities have also been undercut. On the one hand, federal and state fiscal crises have induced and promoted new forms of public-private collaboration into the culture of natural and physical sciences. The key is that these are new forms of public-private relations, not that public-private relations are new. (See Kerr, 1963; Hightower, 1973; Kloppenburg, 1988; Shapin, 1996; Slaughter and Leslie, 1997; Delanty, 2001; Etzkowitz, 2002; Mowery et al., 2004.) On the other hand, multicultural politics has redefined citizenship and culture in a manner that has decentered the canonical Western texts of the humanities. ${ }^{3}$ Here, we will only deal with the first of these two uncertain movements towards a postmodern university.

Recent debates over the changing role of universities underscore the rise of what Clark (1998) has called "the entrepreneurial university," with its new relations to industry and government. This new institutional form, deemed "the triple helix" by Etzkowitz and Leydesdorff $(1998,2000)$, is part and parcel of 1) a restructuring of the intellectual commons tied to fiscal crises of states and nations (Kleinman and Vallas, 2001), 2) the broad-scale patterns of the commodification of knowledge (Nentwich, 2001; Suarez-Villa, 2001), and 3) the rising centrality of information and technology transfers in economic development (Etzkowitz, 2003). On the one side of the debates are those who contend the university is a site for intellectual struggle and the open-ended pursuit of knowledge. For these people, neither the capitalist marketplace nor the fiscal demands of universities ought to be the driving force behind public research endeavors undertaken within the ivory towers (Krimsky, 1999). On the other side are those who argue that, under contemporary conditions of fiscal constraint and global competitiveness, universities must necessarily be engines of growth in a knowledge-based society. Here, academic research ought to pursue discoveries and inventions that are marketable and primarily train students to be employable.

Underlying this debate is a concern with academic freedom. If the university is to be a site of intellectual struggle, then academic freedom is best protected by commitments to intellectual diversity within and across departments, though this is not to say that social norms and values will not constrain the boundaries of absolute academic freedom (e.g., Benjamin and Wagner, 1994). If universities are to be largely oriented toward engines of economic and fiscal growth, then academic freedom is directly tied to institutional income generation and private profit motives. Those who are interested in pursuing marketable ideas will be free within that arena, while those more interested in the kind of knowledge Krimsky (2003) calls "science in the public interest," will be marginalized and will find it harder to earn tenure and more difficult to hold on to Full-Time Equivalents (Bok, 2003).

These debates would be arcane and of limited interest if the public, social movements and business did not care about the kind of science practiced, knowledge generated, and service provided by public institutions of higher learning. This, however, is not the case (e.g. Menand, 2002). There are apparently three lay philosophies regarding university-industry relations. First, there is the idea of separate (but possibly equal) spheres of research and influence. Second, that universities and industry should be sharing resources and ideas, but that neither should lead. Finally, there are some who feel that given the profitability of industry, universities should expect some kind of monetary flow from that sector of society, while universities should be willing to share ideas with industry. In each case, academic freedom is involved, and various groups have a vested interest in the final definition. The development and implementation of an industrial contract with a major university offers a unique opportunity to see how these concerns develop, are maintained, and attenuate. We now offer a brief historical account of UCB as a context in which UCBNA can be understood. 


\section{Historical controversies with regards to science and society within the College of Natural Resources at UCB}

The University of California is unique among state universities in that it possesses the status of being an institution held in the public trust by the university's Board of Regents. Douglass (2002: 6) notes that "While not completely autonomous from lawmakers, the University has had the rare opportunity to shape its management structure and ultimately its future." The nature of the public trust is a double edged sword, however, in that while the university has greater autonomy, that autonomy can both distance the system's administration from the legislature and, at times, alienate the university from the body that allocated core operating expenses. This situation is perhaps part of the background for recent draconian cuts in higher education by the California legislature.

The history of UCB shows that tension about its place has been a point of contention for years. At the turn of the last century, Progressive politics and politicians came to the fore and sought to reform higher education.

Determined to break both the power of the Southern Pacific Railroad and rampant political corruption, California's Progressives took inspiration from "the Wisconsin idea" that made higher education a central ingredient in modernizing the state ... Progressive education leaders envisioned an integrated tripartite state system consisting of the junior colleges, the normal schools, and Berkeley. Although the Progressives' power declined after 1912, their legacy was permanent. (Leslie, 2001: 997)

In this way, the university has effectively sought to bring intellectual, academic and scientific excellence to the Progressive interpretation of the dual Enlightenment goals for universities - the development of objective science and informed citizens (Readings, 1996) while addressing the differential capacities of institutions to generate science and the uneven academic backgrounds of the populace. However, the complexity of the coordination of the development and expansion of the university system was more than could be rationalized during the highly sectional battles for the development of California during the first third of the twentieth century. Deepening this struggle was the devastating economic and fiscal effect of the Great Depression.

The New Deal, a connection with the Carnegie Foundation, and some Progressive politicians promoted a core institution characterized by standardized, rationalized and efficient planning for the University of California (UC) system (Douglass, 2002). In addition, intensification of an already remarkable system of shared faculty and administrative governance within the UC system helped to model the system in its current form. Changes in public support for the university since the late 1970s combined with the rising cost of research and academic infrastructure-not to mention federal and state deregulatory incentives-have encouraged the emergence of a more entrepreneurial university and faculty. As such, faculty participation in shared governance has broadly declined as the corporatist tendencies of research have led administrators to operate more independently of the faculty body. One consequence of this with respect to UCBNA was that many faculty and graduate students felt that the pursuit and negotiation of the Agreement occurred behind their backs, or was sprung on them, and thereby suborned the historical commitment of the university to shared governance.

Progressivism and independent administrators are only part of the context in which UCBNA played out. UCB is the Land Grant institution of California, and as such, it is expected to fill the needs of the agricultural community of the state. What has been contested has been the kind of agricultural community desired or pursued by UC re- 
searchers. For example, even prior to the Depression, researchers such as Paul Taylor (1928, 1937, 1950, 1968, 1979) were investigating the living and working conditions of impoverished migrant field workers of many ethnic and racial backgrounds in California and across the country. Taylor's work, like that of the more popular writings of Carey McWilliams (1939) in Factories in the Field, was also deeply committed to proliferation, promotion and sustainability of small farms.

Perhaps most celebrated in this social scientific tradition are the attempts to suppress the work of Walter Goldschmidt (1946) in As You Sow. Funded by the United States Department of Agriculture's Populist Bureau of Agricultural Economics, and directed by Taylor, Goldschmidt documented, compared and contrasted the demographic and community characteristics of an agricultural community dominated by large, corporate farms and another structured around small family farms. Following national outrage from the Farm Bureau, Goldschmidt, an anthropologist, was effectively forced to become an Africanist and the Bureau of Agricultural Economics was eliminated.

Of greater importance to our study, though at best indirectly related to these issues, the post-war boom in California led to the development of a number of new branch campuses across the UC system. Here, the emergence of UC Davis-previously the UC Farm, and UC Riverside-earlier the Citrus Experiment Station, was instrumental in moving a great deal of the applied agricultural research out of Berkeley during the 1950s and 1960s. This situation shifted much of the focus of research within the College of Agriculture at Berkeley to the point that the name was changed in 1974 to the College of Natural Resources (CNR). Since that time, both sides of the Progressive-Populist dynamic on the Berkeley campus moved away from the more applied focus of traditional Land Grant agricultural research to a more basic technoscientific set of concerns.

During this shift Populist agricultural traditions were extended into natural resource economics by Taylor. However, they found their most resonant example-at least with respect to this study - in the emergence and institutionalization of the Division of Biological Control within the Entomology Department in the late 1960s and early 1970s. A major activity of the Entomology Department during the post-war years was the applied testing of pesticides for agrichemical corporations. Following on the publication of Rachel Carson's (1962) Silent Spring, facing the increasing frequency of pest resistance to agrichemicals, and in the context of United Farm Worker campaigns centered on the health implications for farm workers of pesticide use and abuse, young scholars in the Entomology Department rejected what they saw as socially and ecologically destructive applied work of testing pesticides and pursued what they saw as more socially and environmentally responsible research into the biological and (agri)cultural control of pests (Pickett, 1949; Metcalf, 1959; Van den Bosch, 1978).

Work done by representatives of this division laid the groundwork for, among other things, the development of the fields of integrated pest management and agroecology, two intellectual pillars of alternative and organic agricultural production systems around the world. It could go without saying that biological control, integrated pest management, agroecology and organic production have historically been linked to social movements and agricultural traditions on the socially and ecologically Populist side of the political and scientific ledger. For faculty and movements committed to the values and sciences tied to agroecology, a sense of crisis existed before UCBNA when restructuring of the biological sciences at UCB and of the majority of the departments within CNR during the 1980s and 1990s, collapsed Entomology and Biological Control and other more Populist departments into a catch-all department, Environmental Sciences, Policy and Management. At the same 
time, the Progressive scientific tradition was concentrated in Plant and Microbial Biologythe department that UCBNA primarily sponsored.

In this context, and given the history of struggle between the large organic movement and industrial agricultural operations in the state (e.g., Kimbrell, 2002), those who saw the linking of the College of Natural Resources to an agrichemical giant in UCBNA were primed for protest. Add genetically engineered agriculture - a globally contested technology in its own right - to this mix, and the volume of protestation only went up. Given Novartis' interest in biotechnology, it could be assumed that money given to a department that focuses on molecular biology would be used to pursue genetically engineered products. In fact, many of the supporters of UCBNA felt this was the main reason for concern among some faculty members who opposed the Agreement, which will become evident in our analysis below. Even if genetic engineering was not part of the equation, the fact that Novartis was gaining such a strong foothold within the College of Natural Resources would likely have set off alarms.

The Agreement might still have gone relatively unnoticed if UCBNA had taken place on a college campus without the history recounted above and UCB's reputation for being a bastion of student activism. While the "Free Speech" movement and student protests of the 1960s were three decades past by the time of UCBNA, some continued to use that protest framework to make sense of the Agreement, especially those in the media who often look for interpretive anchors to make sense of current events (Zelizer, 1993). The key to all of this is that proponents of the Agreement tend to look forward through the lens of technological hopefulness and faith while opponents tend to see the future in light of a largely tragic past-whether focused on the kind of science being done within CNR or the kind of funding for science related to the university.

\section{Data}

The data that are the bases for the following analyses come from three sources-internal documents from UCB, popular newspaper coverage, and interviews with individuals involved with UCBNA. The public relations campaign at UCB — at least the one we were privy to-consisted of articles that appeared in the Berkeleyan (nine articles), the faculty and staff newspaper at UCB, and four press releases from the UCB Public Information Office web site. Both the Berkeleyan and the UCB Public Information Office are housed in the same suite of offices, and authors for these releases were often the same. All 13 releases were found using the Internet, so other releases may have been produced which were not available on their web site. Six of the articles appeared between November and December 1998, three appeared in 1999, two in 2000, and two in 2003. As one person from the UCB Public Information Office mentioned, much of the information concerning the Agreement made available to the press and public prior to its signing was provided by the Dean's office in the College of Natural Resources and by faculty from the Department of Plant and Microbial Biology. The first popular press article appeared in October 1998, while the first four press releases from the Public Information Office were available on 23 November 1998, nearly a month after the Agreement was made public (though other internal documents were available prior to these releases).

From the popular press, articles were collected using Lexis-Nexis, six newspaper archives (San Francisco Chronicle, San Francisco Examiner, San Francisco Guardian, San Jose Mercury News, Contra Costa Times, Daily Californian), and articles supplied by an individual at UCB who was an administrator and had a lead role in the negotiations of the 
Agreement. ${ }^{4}$ Of the 71 articles found on the topic between October 1998 and June 2002, 29 (40.8 percent) appeared between October and December of 1998, meaning that much of the attention given to UCBNA attenuated shortly after it was signed. This is unsurprising, as research undertaken within the parameters of the Agreement did not result in controversial technologies or products at the time of this writing, nor were there newsworthy protests on or around campus after the signing. It should be noted, however, that some news reports did come out in 2002 when a UCB professor (Ignacio Chapela) who was an opponent of the Agreement reported in Nature that traces of genetic modification had been found in Mexican maize landraces (Quist and Chapela, 2001). Some of the news coverage did mention the Agreement as a possible catalyst for concerns with both the scientist conducting the research and the research itself. Dr. Chapela continued to be a newsworthy item as late as 2005 following his denial for tenure at UCB.

In addition to the internal and external articles, 85 individuals involved with UCBNA were interviewed as part of a larger research project. This included 45 faculty members, 16 UCB administrators, six UCB graduate students, five UCB postdoctoral students, five from agricultural or environmental organizations, three individuals from Novartis, three farmers or others representing agricultural interests, one reporter, and one person who had been a graduate student and then helped oversee the administration of UCBNA. Interviews were open-ended, semi-structured, and recorded with notes taken during and after the interview. Transcriptions were coded using NVIVO software.

\section{Analyses and findings}

\section{The internal campaign}

On-campus public information sources tended to promote the Agreement, emphasizing the ways that UCBNA 1) accommodated, even enabled, academic freedom and 2) would serve the public interest through licensing patented information for public sale by Novartis. The first use of the term "academic freedom" appeared in a press release presaging the Agreement's signing by almost two weeks, on 11 November 1998-which also happened to be the first Internet-available UCB press release to mention the Agreement. According to this account, Novartis was selected, over four other competing firms, as the industrial partner for PMB "because of the company's interest in safeguarding academic freedom" (Mena and Sanders, 1998). Two other releases that same day further stressed the issue. Both ("Questions and Answers on the UC Berkeley-NADI Research Agreement," 1998; "Collaborative Research Agreement-Condensed Version," 1998) pulled text from the Agreement to make the point. For example:

There are two important principles underlying academic research in the University: free exchange of ideas and timely dissemination of results. These principles apply to research carried out in PMBD and to any research $\mathrm{NADI}^{5}$ may sponsor in the University. University faculty will be free to publish and disseminate the results of their research. ("Collaborative Research Agreement-Condensed Version," 1998)

The idea is that UCBNA fit well within the traditions of the academy with regards to conducting research and freely disseminating findings. The only caveat was that the Agreement contained a (conventional and non-controversial) 30-day delay on submission of publications, which allowed for corporate review of the work and its desirability with respect to pursuit of patents. If deemed worthy of patent by Novartis, the delay could be extended to 90 days. 
In addition to the standard delay of submissions, according to the press releases, a laboratory building to be controlled by NADI was proposed to be built close to but not on campus to foster collaboration between Novartis and PMB scientists. The commitment to academic freedom, and the (never realized) possibility of new laboratory facilities, along with US\$5 million annually for five years, was said to "enable PMB researchers and their students to work at the forefront of their field" ("Questions and Answers on the UC Berkeley-NADI Research Agreement," 1998).

Eight days after the Agreement was signed, and following the Thanksgiving holiday, the faculty and staff newspaper, the Berkeleyan, again stressed Novartis' commitment to academic freedom. Further, the Agreement was said to be an experimental form of corporate-university collaboration, one that would be closely monitored (Sanders, 1998). This article also reported that some students were concerned with UCBNA, and that a group of activists had hurled pies at the College of Natural Resources' Dean Gordon Rausser and Novartis' CEO Douglas Watson during the signing. The activists were said to have been "subdued by campus police" and the student concerns were seemingly managed when Rausser and other faculty members spoke to them.

A week later, just before the year-end semester break, the Berkeleyan published a question-and-answer article on UCBNA. One of the questions answered was: "Is it fair to give one company an inside track?" The answer, nodding again to the issue of academic freedom and emphasizing the opportunity for greater collegiality, suggested that by sponsoring a whole department, faculty members could now discuss their research with other experts and each other, instead of having them feel constrained as a result of different researchers contracting with competing companies ("More on CNR's Research Agreement with Novartis," 1998).

Nothing more was published in the Berkeleyan on the Agreement until 17 February 1999 when David Noble from York University, who has been a long-time critic of the historical structure and social priorities of scientific and technological development, gave a talk to the campus community which was critical of corporate incursions into institutions of higher learning. ${ }^{6}$ Noble argued that corporate control of universities was having an impact on, and limiting of, the directions of academic research. He anticipated that UCBNA would be a prime example of this phenomenon. Countering Noble's presentation, the article quoted Dean Rausser, who had not attended the talk, as contending that Noble must not have read the Agreement, and could not therefore understand how UCBNA was "inherently consistent with the culture and values of UC Berkeley" (Cockrell, 1999a).

Given that there was nothing to report until research based on the Agreement started to come to fruition, and that the initial furor over UCBNA moved to the background after the holidays, it is not surprising that another eight months went by before the next article to mention the Agreement was published. The academic freedom bell tolled again, though in a different register. In this case, UCB historian David Hollinger was quoted as suggesting that the main legacy of the Agreement might "prove to be strict guidelines for evaluating future deals in terms of the protection of free inquiry" (Cockrell, 1999b). In the next article, which was published in 2000, the pendulum had begun to swing the other way, as one UCB professor noted that agreements such as UCBNA needed to be scrutinized to "prevent the loss of control over our research" (Hunter, 2000). The contention was not that UCBNA had affected academic freedom, but that if the UCB campus did not have access to these kinds of agreements, or that only certain colleges received them, the playing field would no longer be level. In other words, such agreements would need to be handed out to more than one university, or academic freedom would be compromised by giving only a handful of universities the ability to conduct research in certain fields. 
Nothing else appeared on UCBNA until 2003, when a Berkeleyan article and a media release were made available. In January of that year, the end of UCBNA was anticipated and it was argued that the Agreement had not caused an unusual change in the kinds of biotechnology research pursued by PMB faculty. In fact, the Agreement was said to have opened new research streams. As with the report on Noble's talk, criticism leveled at the UCBNA — one faculty member saying it was "a contract with the devil"-was undermined by the inclusion of an alternative position, in this case UCB's vice chancellor for research, Robert Price, who reiterated that Novartis (and Syngenta) had not influenced research. On a somewhat self-congratulatory note, UCB was suggested to have been able to withstand any pressures that might have arisen from industry; though a caveat was made that smaller institutions may not be so lucky (Sanders, 2003). The final media release that mentioned the Agreement did so only in passing, listing it as an accomplishment of outgoing Chancellor Robert M. Berdahl.

What is clear from this account is the fact that the UCB Public Information Office was interested in alleviating concerns with corporate control on campus. The key was that the Agreement fostered progressive scientific development and was written in a manner that protected academic freedom. Few comments were included that mentioned the controversies around biotechnology, and those that did mention the topic treated it as unproblematic. We now turn to the popular press to highlight similarities and differences in the wider public presentation of UCBNA.

\section{Popular news coverage}

The positive framing of the Agreement provided by the UCB Public Information Office was not echoed by reports in other publications. In fact, changes in the outside coverage of the Agreement were minor, as the controversy began with the very first article, unlike the trajectories of other public controversies (e.g., Gamson and Modigliani, 1989; Ten Eyck and Williment, 2004). In direct contrast to campus-based materials, threats to academic freedom were immediately raised, as reporters and editorials within the mass media challenged the meaning of financial ties to a company with such deep pockets. The first article appeared on the front page of the 9 October 1998 edition of the San Francisco Chronicle (two days before the first UCB press release) and presented UCBNA in these terms:

Alliances with industry have become commonplace throughout academia as cashstrapped institutions seek both financial salvation and technological know-how. But the unusually broad scope of the Berkeley-Novartis deal is expected to raise new questions about the danger of corporate influences subverting academic freedom. (Hall, 1998: A1)

The headline announced a possible US $\$ 50$ million agreement between a biotechnology firm and UC Berkeley, a statement sure to raise red flags among some political and sustainable agriculture activists in the Bay Area.

This report had an impact on campus. Five days later, UCB graduate students expressed the following in a letter to the editor:

Your article (October 9) on the proposed alliance between the University of California at Berkeley's College of Natural Resources and the Swiss biotechnology company, Novartis, says the US $\$ 50$ million "deal is expected to raise new questions about the danger of corporate influences subverting academic freedom." How true. As graduate students in the college, we are seriously concerned, especially in light of how the process has unfolded. Negotiations have taken place behind closed doors with little 
faculty or student input. Dean Gordon Rausser has predicted that most concerns will vanish once the full details of the plan become known. However, students requesting information from the Dean's Office have been turned away, or had their notes confiscated after viewing limited materials. Faculty members were directed not to discuss the agreement with the press. (Letter to the Editor, 1998: A20)

Recall that internal communications mentioned that student concerns were addressed by Dean Rausser after UCBNA was signed. It could be that these students were later acknowledged, that (at least) two different interpretations of UCBNA and Rausser's explanation for UCBNA existed, or that these students were never satisfied with the situation.

The story became national in December when the Washington Times reported a piethrowing incident at the signing of the Agreement. For the Washington Times, however, the struggle over biotechnology was key:

Protesters inspired by the Green Party twice in the past two weeks threw pies at the faces of top University of California officials for making big-money deals with companies that market genetically engineered food products. ...

One representative of the Green Party of California, Hank Chapot, said his group has long opposed genetically engineered agriculture. "It can have vast unintended consequences," he said. Mr. Chapot said genetically altered corn produced by Novartis in Europe has cross-pollinated nearby natural corn. So far, there have been no reports of negative consequences of such accidental interbreeding ... (Elias, 1998: A4)

This spin on the issue highlights the point made earlier that the groups involved were talking past each other. The "Greens" were concerned about biotechnology entering a college campus, while the internal campaign was about academic freedom (Elias, 1998: A4).

The trajectory of this story stayed much the same throughout the five years of UCBNA, though reports in the popular mass media quickly subsided after the signing. A few pieces did appear in such publications as US News and World Report (October, 1998), the Atlantic Monthly (March, 2000), and the Journal of Higher Education (June, 2001) all raising concerns over biotechnology and/or academic freedom. That the trajectory stayed much the same can be seen in an article appearing in the San Francisco Chronicle in December 2003, which discussed the controversial tenure review for Ignacio Chapela. According to the article,

A UC Berkeley assistant professor and critic of the biotech industry has lost a long tenure battle to what he believes is corporate corruption of academic freedom.

UC officials confirmed Thursday that tenure had been denied to Ignacio Chapela, whose disputed research found that genetically engineered corn had infiltrated native maize in Mexico. He was also a leading critic of a controversial 1998 deal to give Novartis, a Swiss-based biotechnology company, privileged access to UC plant research in exchange for US\$25 million. (Burress, 2003)

Chapela's work is seen by opponents of the Agreement who emphasize the biotechnological framing of their position as providing scientific support for their opposition. Chapela's extraordinary tenure process, as reported by Burress - and its negative outcome (though Chapela was given tenure later) is then linked to the issue of academic freedom. ${ }^{7}$

This brief snapshot of the popular press coverage of UCBNA is indicative of the 71 articles found on the issue, including the UCB student newspaper, the Daily Californian. These portrayals seem not to reflect the public information work being done on campus 
other than to use some of the facts which were then interpreted in ways different than those developed internally. Information dissemination, however, is only one role of the media. The other is getting people to (re)act, though many media studies only focus on reactions within news articles or campaigns (e.g., Hilgartner and Nelkin, 1987; Lange, 1993). We turn now to the ways in which people connected to UCBNA were discussing its public presentation.

\section{The (re)actions}

The public presentation of UCBNA shows the tension that existed between supporters and opponents, and calls for a framework that would help make sense of the situation. Given the controversial nature of UCBNA, we turned to a general social problems model to ground the interpretations of the public controversy by those most closely involved. Blumer (1971) and Hilgartner and Bosk (1988) defined a social problem as something that appears in a public arena, such as the mass media, which leads to public awareness and legitimation claims by various experts and authorities. The different spins and framings placed on UCBNA clearly show that the Agreement was widely seen as a social problem. In addition, the introduction of reactions to the coverage expands on the original social problems approach by showing that interpretations of a problem are not homogeneous. In fact, as will be seen, proponents of UCBNA argued that those opposed to the Agreement were against biotechnology, while those opposed to the Agreement were typically more concerned with academic freedom.

This "bounce" or "ripple" effect where actors who have a vested interest in the issue react to what is taking place in the press, is often overlooked in studies of media portrayals of problems. Many studies that focus on public presentations look at the content of the message, with some discussion of content or final legislative actions (e.g., Best, 1991; Binder, 1993; Lange, 1993). This can affect actors with either direct or indirect ties to the issue, as those with direct ties may find that they have to answer questions about their behavior (e.g., a company representative being asked if funds given to a university will affect research at that university) while those with indirect ties may decide to take a different route (e.g., a college administrator at another college deciding to only accept funds from federal agencies). Both media effects are important for understanding the impact of the Agreement as many different actors were (potentially) affected by it.

That the media reports were being followed is summed up by one UCB administrator who said, "you could not ignore Novartis. It was in The Chronicle of Higher Education, in the local paper, everyone was talking about it. It animated the whole campus in those years." Or, as another administrator contended, "we would be worried if there wasn't any press" because the Agreement signaled a shift in how university-industry relations were constructed. At the same time, not surprisingly, some of our respondents thought the media coverage was inappropriate. As one professor concluded, the coverage "generated a lot of heat, but it didn't give much light to the larger issues." A number of respondents thought the public relations campaign was flawed from the beginning when Dean Gordon Rausser tried to control the information flows surrounding UCBNA.

These accounts highlight the fact that the Agreement and its public presentations were impacting the UCB campus, and, in fact, many of these responses were generated without our asking about reactions to the coverage. One administrator who supported UCBNA mentioned that anything that went to the public just fueled existing activist resistance to biotechnology, while another said that the controversy was tied to ideological opposition related to genetically modified organisms and globalization. This could be overcome, 
however, as a top administrator said that agricultural biotechnology was much like the semiconductor industry a number of years ago which was troubled with problems of secrecy.

Opponents, on the other hand, were concerned with the institutional process by which UCBNA was developed. For example, one professor interviewed found that,

the whole thing was so carefully stage managed that before anyone [could say] "and what do you people think?," the whole subtext was "never mind, it's a done deal ... don't put any effort into this, don't take any risks ... you've already lost".

Another concern was with the role of the university. As one professor made clear, the research mission is influenced by private industry and political agents, which makes it even more difficult to resist. The Agreement was just one more step down this road. Other opponents echoed this sentiment by saying that corporate control was becoming the norm within universities (UCB included), leaving various clients (usually small farmers) behind.

While these reactions were typical, many others existed on the UCB campus and with others involved with UCBNA. The main issues were that the Agreement was constructed behind closed doors with little or no input from faculty members, that the public relations campaign was also staged from a proponent point of view, that industry interests were overshadowing academic freedom, and that biotechnology was seen as a deal with the Devil. What should be clear is that most proponents saw nothing wrong with the development of UCBNA, and many of these individuals thought opposition was mainly ideological and based on Novartis' interests in biotechnology, while opponents rarely mentioned that biotechnology was the problem, and, instead, insisted that they were given very little say in the development or maintenance of the Agreement.

\section{Conclusions}

The role of universities and thoughts on linkages between the academy and industry are changing, and these changes are being supported and challenged depending on the vested interests of those involved. Add to this a campus and location with a history of activism and a controversial technology, and the social landscape was ripe for protest. Our focus in this paper was to highlight the ways in which the five year, US\$25 million agreement between the University of California at Berkeley and Novartis was portrayed in the internal public relations campaign, as well as the mass media, and how these presentations affected people with vested interests - both supporters and opponents-in the Agreement and the role of the university.

We found that the internal campaign mostly ignored the controversial aspects of UCBNA, opting to report that concerns with such things as academic freedom were written into the contract. The popular press, on the other hand, treated the Agreement as controversial from the start, reporting activist and student concerns, raising the flag around biotechnology, and quoting sources concerned with corporate control over university research agendas. For those with ties to UCB, supporters tended to think that opposition was based on concerns with biotechnology, and detractors were likely to mention concerns over secret negotiations and corporate control.

In the end, we found that the Agreement had very little impact on the Plant and Microbial Biology Department or biotechnology as a research area, as the size and complexity of UCB and the University of California system seems to have absorbed UCBNA with little change in standard operating procedures. The larger controversies over academic 
freedom and corporate control continue, and it is here that the Agreement may have the biggest impact. As university administrators seek new revenue streams, what, if any, lessons will have been learned when industry comes calling? In addition, if little comes out of the UCBNA situation, will industry be more bold in asking for more from the ivory tower?

Finally, we need to question the role of public portrayals of such controversies. The complexities of academic freedom, university-corporate relations, and genetic engineering are deep and various, and unlikely to be settled in a 1000 word report or column in a national newspaper. If the public is to be informed that such debates are taking place, can the press be expected to carry much of the load of educating them? Siranni and Friedland (2001) have found a few examples of civically engaged media where community leaders have worked with reporters to solve problems, but often at the expense of becoming focused on only one or two issues. Can Bay Area newspapers forget about Silicon Valley to focus on campus polemics? If this is a debate that those involved feel the public should be engaged with, it will be important to make efforts to reach the public to pique their interests and get them involved.

\section{Acknowledgements}

An earlier version of this paper was presented at the annual meetings of the Rural Sociological Society, Sacramento, CA, August 2004. Funding for this study was provided by the University of California at Berkeley Senate, though the statements presented here do not necessarily reflect the opinions of that organization. We would like to thank Lawrence Busch, Dawn Coppin, Brad Shaw, and Jason Konefal for their work on this project and the wider report off of which it was built: Lawrence Busch et al., 2004, External Review of the Collaborative Research Agreement between Novartis Agricultural Discovery Institute, Inc. and The Regents of the University of California (East Lansing, MI: Institute for Food and Agricultural Standards, Michigan State University). Available at: http://evcp.chance. berkeley.edu/documents/Reports/documents/NovartisBerkeleyFinalReport071204.pdf

\section{Notes}

1 The enrolment of the whole department in the Agreement-except for two professors who opted out-was subsequently modified when faculty affiliated with the department but located at the USDA's Plant Gene Expression Center amended their relationship to UCBNA with a related, though separate, Cooperative Research and Development Agreement CRADA (Day-Rubenstein and Fuglie, 2000).

2 Our study of the Agreement results from the remarkable breadth and scope of faculty-administration shared governance at UCB. In the context of the controversy over the Agreement's process and concerns about its consequences, the Faculty Senate at Berkeley worked for a number of years to generate an outside study of the firestorm of debate on campus - and in the Bay Area-over the relationship between Novartis, UCB, CNR, and PMB. Following a competitive grant proposal process, a multidisciplinary group of faculty here at Michigan State University, led by Dr. Lawrence Busch and including the authors, was selected by the Faculty Senate to execute that study. This research is a component of our larger study.

3 The Culture Wars and Science Wars of the 1990s are indicative of these two crises. Here, diverse forms of constructionism historically associated with the humanities have been introduced into social studies of science raising questions as to the representational purity that science provides nature. This has reignited historical battles between idealist and realist philosophical positions, but this time in public.

4 To check for other newspaper and magazine articles, as well as looking for more perspectives on the Agreement, a Yahoo! Internet search using the phrase "University of California, Berkeley and Novartis" was conducted. While there were a couple of web sites related to the Agreement, these were similar to what was supplied by other sources. In fact, some of the web sites referenced articles such as the one appearing in the Atlantic Monthly.

5 NADI is the Novartis Agricultural Discovery Institute.

6 Noble's most prominent works are 1977's America by Design: Science, Technology and the Rise of Corporate Capitalism, 1984's Forces of Production: A Social History of Industrial Automation, 1993's Progress Without 
People: New Technology, Unemployment, and the Message of Resistance, and 2001's Digital Diploma Mills: The Automation of Higher Education.

7 Media coverage and interviewees also raised the specter of UCB's activist history, though usually with reference to criticisms of university-industry relations made by Mario Savio, one of the leaders of Berkeley's Free Speech Movement in the early 1960s (Press and Washburn, 2000; see also Zelizer, 1992). While UCB's role in struggles over the science and politics of agriculture was central to the understanding of the Agreement by on-campus opponents, the campus's role in historically more urban forms of social protest was more on the minds of offcampus opponents and reporters.

\section{References}

Benjamin, E. and Wagner, D.R., eds (1994) Academic Freedom. San Francisco: Jossey-Bass.

Best, J. (1991) “'Road Warriors' on 'Hair-Trigger Highways': Cultural Resources and the Media's Construction of the 1987 Freeway Shootings Problem,” Sociological Inquiry 61(3): 327-45.

Binder, A. (1993) "Constructing Racial Rhetoric: Media Depictions of Harm in Heavy Metal and Rap Music," American Sociological Review 58(6): 753-67.

Blumer, H. (1971) "Social Problems as Collective Behavior," Social Problems 18(3): 298-306.

Bok, D. (2003) Universities in the Marketplace. Princeton, NJ: Princeton University Press.

Burress, C. (2003) "UC Won't Give Tenure to Critic of Biotech," San Francisco Chronicle 12 December: A25.

Carson, R. (1962) Silent Spring. Boston, MA: Houghton Mifflin.

Clark, B.R. (1998) Creating Entrepreneurial Universities: Organizational Pathways of Transformation. New York: Pergamon Press.

Cockrell, C. (1999a) "David Noble Critiques 'Commercialization of Universities,"” Berkeleyan 17 February. URL: www.berkeley.edu/news/berkeleyan/1999/0217/noble.html

Cockrell, C. (1999b) "Money Changes Face of Higher Ed: Historian Highlights 90s-style Challenges to Academic Institutions," Berkeleyan 8 September. URL: www.berkeley.edu/news/berkeleyan/1999/0908/money.html

"Collaborative Research Agreement-Condensed Version" (1998) University of California, Berkeley news release, 23 November. URL: www.berkeley.edu/news/media/releases/98legacy/agreement.html

Day-Rubenstein, K. and K.O. Fuglie (2000) "The CRADA Model for Public-Private Research and Technology Transfer in Agriculture," in K.O. Fuglie and D.E. Schimmelpfennig (eds) Public-Private Collaborations in Agricultural Research, pp. 155-174. Ames, IA: Iowa State University Press.

Delanty, G. (2001) Challenging Knowledge: The University in the Knowledge Society. Buckingham: Open University Press.

Douglass, J.A. (2002) "From Multi- to Meta-University: Organizational and Political Change at the University of California in the 20th Century and Beyond," CSHE Paper 4-02. Berkeley, CA: Center for the Study of Higher Education, University of California at Berkeley.

Elias, T.D. (1998) "Pies Fly Over University's Deals on Genetically Altered Foods," Washington Times 4 December: A4.

Etzkowitz, H. (2002) MIT and the Rise of Entrepreneurial Science. London: Routledge.

Etzkowitz, H. (2003) "Innovation in Innovation: The Triple Helix of University-Industry-Government Relations," Social Science Information 42(3): 293-337.

Etzkowitz, H. and Leydesdorff, L. (1998) "The Endless Transition: A 'Triple Helix' of University-IndustryGovernment Relations," Minerva 36(3): 203-8.

Etzkowitz, H. and Leydesdorff, L. (2000) "The Dynamics of Innovation: From National Systems and 'Mode 2' to a Triple Helix of University-Industry-Government Relations," Research Policy 29(2): 109-23.

Gamson, W.A. and Modigliani, A. (1989) "Media Discourse and Public Opinion on Nuclear Power: A Constructionist Approach,” American Journal of Sociology 95(1): 1-37.

Gaskell, G. and Bauer, M.W., eds (2001) Biotechnology, 1996-2000. London: Science Museum.

Goldschmidt, W.R. (1978 [1946]) As You Sow: Three Studies in the Social Consequences of Agribusiness. Montclair, NJ: Allanheld Osmun.

Hall, C.T. (1998) "Research Deal Evolving Between UC, Biotech Firm: Berkeley Campus Could Get US\$50 Million," San Francisco Chronicle 9 October: A1.

Haraway, D.J. (1985) "A Manifesto for Cyborgs: Science, Technology, and Socialist Feminism in the 1980s," Socialist Review 80: 65-107.

Hightower, J. (1973) Hard Tomatoes, Hard Times. Cambridge, MA: Schenkman.

Hilgartner, S. and Bosk, C.L. (1988) "The Rise and Fall of Social Problems: A Public Arenas Model," American Journal of Sociology 94(1): 53-78.

Hilgartner, S. and Nelkin, D. (1987) "Communication Controversies over Dietary Risks," Science, Technology, and Human Values 12: 41-7. 
Hunter, D.L. (2000) "Berkeley Faculty Association Joins National Alliance: New Coalition Focuses Efforts on Critical Issues such as Researching and Intellectual Property," Berkeleyan 10 May. URL: www.berkeley.edu/ news/berkeleyan/2000/05/10/bfa.html

Kerr, C. (1963) The Uses of the University. Cambridge, MA: Harvard University Press.

Kimbrell, A., ed. (2002) Fatal Harvest. Washington DC: Island Press.

Kleinman, D.L. and Vallas, S.P. (2001) "Science, Capitalism, and the Rise of the 'Knowledge Worker': The Changing Structure of Knowledge Production in the United States," Theory and Society 30(4): 451-92.

Kloppenburg, J.R., Jr. (1988) First the Seed: The Political Economy of Plant Biotechnology, 1492-2000. New York: Cambridge University Press.

Krimsky, S. (1999) “The Profit of Scientific Discovery and its Normative Implications," Kent Law Review 75(1): $15-39$.

Krimsky, S. (2003) Science and the Private Interest. Lanham, MD: Rowman Littlefield.

Kuhn, T.S. (1962) The Structure of Scientific Revolutions. Chicago: University of Chicago Press.

Lakatos, I. and Musgrave, A. (1970) Criticism and the Growth of Knowledge. Cambridge: Cambridge University Press.

Lange, J.I. (1993) "The Logic of Competing Information Campaigns: Conflict over Old Growth and the Spotted Owl," Communication Monographs 60(3): 237-57.

Latour, B. (1993) We Have Never Been Modern. Cambridge, MA: Harvard University Press.

Law, J. (1991) A Sociology of Monsters: Essays on Power, Technology, and Domination. London: Routledge.

Leslie, W.B. (2001) "The California Idea and American Higher Education: 1850 to the 1960 Master Plan-J. A. Douglass," American Historical Review 106(3): 997.

Letter to the Editor (1998) "UC Should Open its Books on Biotech Deal," San Francisco Chronicle 14 October: A20.

McWilliams, C. (1939) Factories in the Field: The Story of Migratory Farm Labor in California. Boston, MA: Little Brown.

Mena, J. and Sanders, R. (1998) "Swiss Pharmaceutical Company Novartis Commits US\$25 Million to Support Biotechnology Research at UC Berkeley," University of California, Berkeley news release, 11 November. URL: www.berkeley.edu/news/media/releases/98legagy/11-23-1998.html

Menand, L. (2002) “Comment: Silly ideas,” New Yorker 78(11): 33-4.

Metcalf, R.L. (1959) "The Impact of the Development of Organophosphorus Insecticides upon Basic and Applied Science," Bulletin of the Entomological Society of America 5: 3-15.

Miyoshi, M. (1998) “'Globalization,' Culture, and the University,” in F. Jameson and M. Miyoshi (eds) The Cultures of Globalization, pp. 247-70. Durham, NC: Duke University Press.

"More on CNR's Research Agreement with Novartis" (1998) Berkeleyan 9 December. URL: www.berkeley.edu/ news/berkeleyan/1998/1209/cnr.html

Mowery, D.C., Nelson, R.R., Sampat, B.N. and Ziedonis, A.A. (2004) Ivory Tower and Industrial Innovation: University-Industry Technology Transfer Before and After the Bayh-Dole Act in the United States. Palo Alto, CA: Stanford University Press.

Nentwich, M. (2001) “(Re-)De-Commodification in Academic Knowledge Distribution?”, Science Studies 14(2): 21-42.

Noble, D.F. (1977) America by Design: Science, Technology and the Rise of Corporate Capitalism. Oxford: Oxford University Press.

Noble, D.F. (1984) Forces of Production: A Social History of Industrial Automation. Oxford: Oxford University Press.

Noble, D.F. (1993) Progress Without People: New Technology, Unemployment, and the Message of Resistance. Chicago: Charles H. Kerr Publishing Co.

Noble, D.F. (2001) Digital Diploma Mills: The Automation of Higher Education. New York: Monthly Review Press.

Nottingham, S. (1998) Eat Your Genes. London: Zed.

Pickett, A.D. (1949) “A Critique on Insect Chemical Control Methods," The Canadian Entomologist 81: 67-76.

Press, E. and Washburn, J. (2000) “The Kept University,” Atlantic Monthly 285(March): 39-54.

"Questions and Answers on the UC Berkeley-NADI Research Agreement" (1998) University of California, Berkeley news release, 11 November. URL: www.berkeley.edu/news/media/releases/98legacy/QandA.html

Quist, D. and Chapela, I.H. (2001) "Transgenic DNA Introgressed into Traditional Maize Landraces in Oaxaca, Mexico," Nature 414: 541-3.

Readings, B. (1996) The University in Ruins. Cambridge, MA: Harvard University Press.

Sanders, R. (1998) “CNR, Novartis Seal US\$25 Million Biotech Research Agreement,” Berkeleyan 2 December. URL: www.berkeley.edu/news/berkeleyan/1998/1202/novartis.html 
Sanders, R. (2003) "Closing the Book on the Novartis Deal? Internal Campus Study Says Lucrative Agreement Didn't Skew Research or Compromise Academic Freedom," Berkeleyan 29 January. URL: www.berkeley.edu/news/berkeleyan/2003/01/29_novart.html

Schonbach, P. (1990) Account Episodes. New York: Cambridge University Press.

Shapin, S. (1996) The Scientific Revolution. Chicago: University of Chicago Press.

Siranni, C. and Friedland, L. (2001) Civic Innovations in America. Berkeley, CA: University of California Press.

Slaughter, S. and Leslie, L.L. (1997) Academic Capitalism: Politics, Policies, and the Entrepreneurial University. Baltimore: Johns Hopkins University Press.

Snow, C.P. (1959) The Two Cultures and the Scientific Revolution. New York: Cambridge University Press.

Star, S.L. and Griesemer, J. (1989) 'Institutional Ecology, 'Translations,' and Boundary Objects: Amateurs and Professionals in Berkeley's Museum of Vertebrate Zoology, 1907-1939," Social Studies of Science 19(3): 387-420.

Suarez-Villa, Luis (2001) "The Rise of Technocapitalism," Science Studies 14(2): 4-20.

Taylor, P.S. (1928) Mexican Labor in the United States, Vols I-III. Berkeley: University of California Press.

Taylor, P.S. (1937) Migratory Farm Labor in the United States. Washington DC: United States Government Printing Office.

Taylor, P.S. (1950) 'The 160-acre Water Limitation and the Water Resources Commission," Western Political Quarterly 3(3): 435-50.

Taylor, P.S. (1968) California Farm Labor. Berkeley, CA: Agricultural History Society.

Taylor, P.S. (1979) Essays on Land, Water, and the Law in California. New York: Arno Press.

Ten Eyck, T.A. and Williment, M. (2004) "The More Things Change. . .: Milk Pasteurization, Food Irradiation, and Biotechnology in the New York Times,” The Social Science Journal 41(1): 29-41.

Van den Bosch, R. (1978) The Pesticide Conspiracy. Garden City, NY: Doubleday.

Zelizer, B. (1992) Covering the Body. Chicago: University of Chicago Press.

Zelizer, B. (1993) "Journalists as Interpretive Communities," Critical Studies in Mass Communication 10: 219-37.

\begin{abstract}
Authors
Alan Rudy is an assistant professor of sociology whose work focuses on the intersection of the sociology of agriculture, science and technology studies and environmental sociology. In addition to working with Dr. Ten Eyck and others on the Berkeley-Novartis study, Dr. Rudy is involved in a six-site comparative regional study of agricultural landscape transitions funded by the National Science Foundation's Biocomplexity program. His theoretical agenda at the moment is concerned with integrating James O'Connor's political ecology and Donna Haraway's material semiotics. Correspondence: Department of Sociology, 316 Berkey Hall, Michigan State University, East Lansing, MI 48824-1111, USA, e-mail: rudya@msu.edu
\end{abstract}

Toby A. Ten Eyck is an associate professor in the Department of Sociology and affiliated with the National Food Safety and Toxicology Center at Michigan State University. His current work is focused on the development, dissemination, and interpretation of mass media risk communication messages. He is currently researching risk messages associated with nanotechnology and obesity. 